\title{
UPAYA MENINGKATKAN AKTIVITAS BELAJAR PKN SISWA DENGAN MODEL PEMBELAJARAN KOOPERATIF TIPE THINK PAIR SHARE (TPS) DI KELAS IV SD NEGERI 040460 BERASTAGI
}

\author{
Rosmawati Br. Tarigan
}

Surel: likesmash600@gmail.com

\begin{abstract}
ABSTRAK
Penelitian ini bertujuan untuk meningkatkan hasil belajar siswa serta aktivitas belajar siswa. Subjek dalam penelitian ini adalah siswa kelas IV SD Negeri 040460 Berastagi dengan jumlah siswa sebanyak 51 orang. Adapun hasil penelitian yakni : 1) Data aktivitas siswa pada Siklus I dan II antara lain: menulis, membaca mengalami penurunan dari $40 \%$ menjadi $33 \%$, aktivitas mengerjakan LKS mengalami peningkatan dari $32 \%$ menjadi $41 \%$, sementara aktivitas bertanya pada teman mengalami peningkatan dari $5 \%$ menjadi $18 \%$, Aktivitas bertanya pada guru menurun dari $18 \%$ menjadi 5\%, Aktivitas yang tidak relevan dengan KBM turun dari $8 \%$ menjadi $3 \%$ yang menandakan perbaikan aktivitas belajar siswa. Dengan model pembelajaran TPS, aktivitas dan hasil belajar siswa mengalami peningkatan. Hasil belajar siswa pada Formatif I menunjukkan 26 orang siswa tuntas secara individu, sedangkan kelas tidak tuntas. Pada Siklus II, tuntas secara individu sebanyak 44 orang siswa, sedangkan kelas adalah tuntas dengan rata-rata siklus I dan siklus II adalah 70,6 dan 83,1 dan persentase ketuntasan klasikal adalah 52,9\% pada siklus I dan $86,2 \%$ pada siklus II.
\end{abstract}

Kata Kunci : Pembelajaran Think Pair Share (TPS), Aktivitas Belajar, Hasil Belajar Siswa.

\section{PENDAHULUAN}

Pendidikan pada dasarnya adalah usaha sadar yang menumbuh kembangkan potensi sumber daya manusia peserta didik dengan cara mendorong dan memfasilitasi kegiatan belajar mereka. Sesuai dengan pernyataan Sukmadinata (2004:4) "pendidikan berfungsi membantu peserta didik dalam pengembangan dirinya, yaitu pengembangan semua potensi, kecakapan serta karakteristik pribadinya kearah yang positif, baik bagi dirinya maupun lingkungannya".

Pelajaran PKn adalah salah satu pelajaran wajib yang ada dalam tingkat sekolah dasar. Lewat belajar PKn siswa diharapkan memiliki wawasan mengenai berbagai hal tentang kenegaraan seperti sitim pemerintahan, pemerintahan kabupaten, pemerintahan kota, pemerintahan provinsi, dan globalisasi. Meskipun materi-materi yang dipelajari adalah materi-materi yang kontekstual dengan dunia nyata ternyata tidak menjamin bahwa siswa dapat memahaminya. Hal ini terlihat dari hasil belajar siswa yang masih rendah. Hanya 20\% siswa saja yang melewati KKM.

Pembelajaran yang dilakukan di kelas masih dilakukan satu arah,

Guru Kelas di SD Negeri 040460 Berastagi 
yaitu pembelajaran hanya berpusat pada guru sementara siswa pasif di tempat duduknya. Meskipun materi pelajaran PKn adalah materi di kehidupan nyata tetapi apabila guru tidak mengajak siswa berpikir bahwa materi yang sedang diajarkan ada kaitan dan manfaatnya dalam dunia nyata maka siswa hanya akan menganggap semua materi tersebut hanya bacaan yang perlu dihafal. Jika demikian siswa tidak akan merasakan manfaat dari mempelajari PKn yang mengakibatkan siswa bosan dan ribut di kelas. Mengingat latar belakang siswa kelas IV di SD Negeri 040460 Berastagi adalah dari keluarga petani dan tinggal di desa, kurang ada dorongan orang tua kepada siswa untuk belajar kembali di rumah. Jika demikian tujuan pembelajaran akan sulit dicapai.

Agar tujuan pembelajaran dapat tercapai maka perlu adanya perbaikan dalam pengajaran $\mathrm{PKn}$ di kelas IV SD Negeri 040460 Berastagi. Untuk itu diperlukan model pembelajaran yang mengaitkan materi pelajaran dengan kehidupan nyata agar siswa merasa perlu untuk mempelajari materi PKn yang diajarkan sehingga dapat berujung pada perbaikan hasil belajar dan aktivitas siswa. Dalam hal ini dipilihlah model pembelajaran Think Pair Share (TPS). Model pembelajaran Think Pair Share (TPS) adalah konsep pembelajaran yang intinya membantu guru untuk mengaitkan antara materi yang diajarkan dengan kehidupan nyata siswa dan mendorong siswa mengaitkan pengetahuan yang dipelajari dengan penerapannya dalam kehidupan sehari-hari dengan melakukan diskusi dengan teman sekelompok dengan saling berbagi pengalaman dalam pembelajaran.

Berdasarkan latar belakang di atas, maka dapat dirumuskan suatu masalah sebagai berikut; 1) Apakah ada peningkatan aktivitas belajar PKn siswa setelah menerapkan model pembelajaran Think Pair Share (TPS) di kelas IV SD Negeri 040460 Berastagi? 2) Apakah ada peningkatan hasil belajar PKn siswa setelah menerapkan model pembelajaran Think Pair Share (TPS) di kelas IV SD Negeri 040460 Berastagi?

Sesuai dengan permasalahan di atas, penelitian ini bertujuan untuk; 1) Untuk mengetahui apakah ada peningkatan aktivitas belajar PKn siswa setelah menerapkan model pembelajaran Think Pair Share (TPS) di kelas IV SD Negeri 040460 Berastagi; 2) Untuk mengetahui apakah ada peningkatan hasil belajar PKn siswa setelah menerapkan model pembelajaran Think Pair Share (TPS) di kelas IV SD Negeri 040460 Berastagi.

Kagan dalam (Atik Widarti :2007) menyatakan manfaat think pair share sebagai berikut:

1. Para siswa menggunakan waktu yang lebih banyak untuk mengerjakan tugasnya dan untuk mendengarkan satu sama lain, ketika mereka terlibat dalam kegiatan think pair share lebih banyak siswa yang mengangkat tangan mereka untuk menjawab setelah berlatih dalam pasangannya. Para siswa mungkin mengingat secara lebih 
seiring penambahan waktu tunggu dan kualitas jawaban mungkin menjadi lebih baik.

2. Para guru juga mempunyai waktu yang lebih banyak untuk berpikir ketika menggunakan think pair share. Mereka dapat berkonsentrasi mendengarkan jawaban siswa, mengamati reaksi siswa, dan mengajukan pertanyaan tingkat tinggi.

Fogarty dan Robin (1996) menyatakan bahwa teknik belajar mengajar think pair share mempunyai beberapa keuntungan sebagai berikut:

- Mudah dilaksanakan dalam kelas yang besar,

- Memberikan waktu kepada siswa untuk merefleksikan isi materi pelajara,

- Memberikan waktu kepada siswa untuk melatih mengeluarkan pendapat sebelum berbagi dengan kelompok kecil atau kelas secara keseluruhan.

Dengan teknik belajar mengajar think pair share yang disebutkan Fogarty dan Robin siswa dilatih untuk banyak berfikir dan saling tukar pendapat baik dengan teman sebangku ataupun dengan teman sekelas, sehingga dapat meningkatkan hasil belajar ranah kognitif siswa karena siswa dituntut untuk mengikuti proses pembelajaran agar dapat menjawab setiap pertanyaan dan berdiskusi.

\section{METODE PENELITIAN}

Penelitian ini dilakukan di SD Negeri 040460 Berastagi yang bertempat di jalan Jamin Ginting
Berastagi Kabupaten Karo. pelaksanaannya pada bulan September sampai dengan Desember Tahun Pembelajaran 2015/2016.

Pengambilan data untuk penelitian ini ditentukan di kelas IV SD Negeri 040460 Berastagi. Subjek yang digunakan untuk pengambilan data adalah kelas IV yang berjumlah 51 orang.

Alat pengumpul data dalam penelitian ini adalah; 1) lembar observasi untuk mengetahui aktivitas belajar siswa ; 2) tes hasil belajar untuk mengetahui hassil belajar siswa.

Penelitian ini berbentuk Penelitian Tindakan Kelas (PTK). PTK pertama kali diperkenalkanoleh psikologi sosial Amerika yang bernama Kurt Lewin pada tahun 1946 (Aqib, 2006 :13).

Penelitian tindakan kelas adalah penelitian yang dilakukan oleh guru di kelas atau disekolah dengan penekanan pada penyempurnaan atau peningkatan proses pembelajaran. Menurut Lewin dalam Aqib (2006 : 21) menyatakan bahwa dalam satu Siklus terdiri atas empat langkah, yaitu perencanaan (planning), tindakan (acting), observasi (observing) dan refleksi (reflecting).

Metode Analisis Data pada penelitian ini digunakan metode deskriptif dengan membandingkan hasil belajar siswa sebelum tindakan dengan hasil belajar siswa setelah tindakan. 
Langkah-langkah pengolahan data sebagai berikut:

1. Merekapitulasi nilai pretes sebelum tindakan dan nilai tes akhir Siklus I dan Siklus II.

2. Menghitung nilai rerata atau persentase hasil belajar siswa sebelum dilakukan tindakan dengan hasil belajar setelah dilakukan tindakan pada Siklus I dan Siklus II untuk mengetahui adanya peningkatan hasil belajar.

3. Untuk penilaian aktivitas digunakan rumus sebagai berikut:

$\%$ Proporsi Aktivitas $=\frac{\text { jumlah skor yang diperoleh }}{\text { jumlah skor ideal }} \times 100 \%$

(Majid, 2009:268)

4. Ketentuan persentase ketuntasan belajar kelas:

Ketuntasan belajar kelas $=\frac{\sum S_{b}}{K} \times 100 \%$

$\Sigma \mathrm{Sb}=$ Jumlah siswa yang mendapat nilai $\geq \mathrm{KKM}$

$\Sigma \mathrm{K}=$ Jumlah siswa

Sebagai tolak ukur keberhasilan penelitian tindakan kelas ini dapat dilihat dari: hasil tes, jika hasil belajar peserta didik yang mampu memperoleh atau mencapai hasil belajar minimal 70, sekurangkurangnya $85 \%$ dari jumlah peserta didik yang ada di kelas tersebut (Mulyasa, 2006:99)

\section{HASIL DAN PEMBAHASAN}

Sebelum dilaksanakan Siklus I dilakukan uji awal untuk menjajaki kemampuan awal siswa dalam materi pokok Pemerintahan Pusat dan
Daerah. Hasil pretes menunjukkan nilai dengan rata-rata 19,4 dengan nilai terendah 0 diperoleh 7 orang siswa dan tertinggi 40 diperoleh 2 orang siswa. Berdasarkan data dapat kita lihat tidak ada siswa siswi yang mendapat nilai di atas kriteria ketuntasan minimal (KKM) atau ketuntasan klasikal sebesar 0\%.

\begin{tabular}{|c|c|c|c|}
\hline \multicolumn{4}{|c|}{ Penilaian aktivitas } \\
\hline No & Aktivitas & Skor & Proporsi \\
\hline 1 & $\begin{array}{l}\text { Menulis dan } \\
\text { membaca }\end{array}$ & 95 & $40 \%$ \\
\hline 2 & Mengerjakan LKS & 77 & $32 \%$ \\
\hline 3 & $\begin{array}{l}\text { Bertanya pada } \\
\text { guru }\end{array}$ & 44 & $18 \%$ \\
\hline 4 & $\begin{array}{l}\text { Bertanya pada } \\
\text { teman }\end{array}$ & 12 & $5 \%$ \\
\hline 5 & $\begin{array}{l}\text { Yang tidak relevan } \\
\text { dengan KBM }\end{array}$ & 12 & $5 \%$ \\
\hline & JUMLAH & 240 & $100 \%$ \\
\hline
\end{tabular}
dilakukan pada saat siswa bekerja dalam kelompok diskusi. Pengamatan dilakukan oleh dua pengamat selama 20 menit kerja kelompok dalam setiap kegiatan belajar mengajar (KBM).

\section{Tabel 1. Aktivitas Belajar Siswa Siklus I}

Dengan pengamatan setiap dua menit, maka nilai maksimum yang mungkin teramati untuk satu kategori aktivitas selama 20 menit tersebut adalah 10 kali. Nilai aktivitas untuk setiap KBM adalah rata-rata dari nilai aktivitas kedua pengamat. Karena dalam satu siklus terdapat dua KBM, maka nilai aktivitas tiap kategori untuk satu siklus adalah ratarata dari aktivitas kedua KBM. 
Selain aktivitas belajar, hasil belajar juga dilihat pada penelitain ini. Setelah berakhirnya pelaksanaan siklus I diadakan tes hasil belajar kognitif yang selanjutnya disebut sebagai formatif I. Hasil belajar kognitif yang diperoleh pada siklus I selama dua pertemuan disajikan dalam tabel 2.

Table 2. Nilai Formatif I

\begin{tabular}{|c|c|c|c|c|}
\hline Nilai & Frekuensi & Tuntas & $\begin{array}{c}\text { Ketuntasan } \\
\text { Klasikal }\end{array}$ & $\begin{array}{l}\text { Rata- } \\
\text { rata }\end{array}$ \\
\hline 100 & 8 & 8 & \multirow{5}{*}{$52,9 \%$} & \multirow{5}{*}{70,6} \\
\hline 80 & 16 & 18 & & \\
\hline 60 & 19 & - & & \\
\hline 40 & 8 & - & & \\
\hline Jumlah & 51 & 26 & & \\
\hline
\end{tabular}

Merujuk pada tabel 2, nilai terendah formatif I adalah 40 berjumlah 8 orang siswa dan tertinggi 100 dengan 8 orang siswa. 27 orang siswa mendapat nilai di bawah kriteria ketuntasan minimal dan ketuntasan klasikal adalah sebesar $52,9 \%$. Nilai ini berada di bawah kriteria keberhasilan sehingga dapat dikatakan KBM siklus I kurang berhasil memberi ketuntasan belajar.

Berdasarkan aktivitas dan hasil belajar kognitif siswa pada siklus I menunjukkan bahwa masih terdapat beberapa permasalahan/ kekurangan dalam pelaksanaan tindakan yang perlu diperbaiki secara lanjut. Beberapa kelemahan pada siklus I yang ditemukan antara lain:

Berdasarkan hasil observasi pada penerapan model pembelajaran Think Pair Share (TPS) siklus I di kelas IV
SD Negeri 040460 Berastagi dapat diperoleh hasil refleksi sebagai berikut:

1. Hasil belajar siswa belum mencapai indikator penelitian, sehingga untuk lebih meningkatkan hasil belajar siswa guru menggali lebih dalam lagi peristiwa-peristiwa kontekstual yang terjadi di dunia nyata agar siswa lebih menyadari kegunaan materi yang sedang dipelajari sehingga siswa dapat meningkatkan minat belajarnya yang berujung pada hasil belajar siswa.

2. Masih terjadi kesalahankesalahan dalam penarikan kesimpulan oleh siswa yang menandakan kesalahpahaman dalam diskusi kelompok.

3. Sebagian siswa belum memiliki rasa tanggung jawab terhadap tugasnya dalam kelompok diperlihatkan dengan aktivitas kerja yang hanya mencapai $32 \%$.

4. Ada 8 siswa yang lebih suka mengerjakan soal sendiri

5. Pada tahap pengajuan pertanyaan sebagian besar siswa tidak memusatkan perhatian dalam mengerjakan LKS, terbukti masih banyak persentase aktivitas yang tidak relevan dengan KBM yaitu $5 \%$.

6. Waktu yang digunakan dalam kegiatan pembelajaran tidak sesuai dengan waktu yang direncanakan sebelumnya. 
Berdasarkan diskusi dengan teman sejawat maka diputuskan tindakan perbaikan sebagai berikut:

1. Penjelasan dan penekanan kepada siswa tentang pembelajaran kooperatif diantaranya kerjasama dalam menyelesaikan tugas, saling membantu dan berdiskusi harus diperhatikan.

2. Guru harus lebih sering mengunjungi kelompok pada saat diskusi berlangsung untuk menghindari siswa ngobrol sendiri di luar materi pelajaran.

3. Guru harus memberikan penghargaan bagi siswa/kelompok yang mendapatkan skor tertinggi dan menyajikan jawaban terbaik.

4. Pengelolaan waktu diharapkan lebih efisien.

5. Guru memberikan informasi kepada siswa bahwa pertanyaanpertanyaan dalam LKS akan ditanyakan kembali pada saat tes agar siswa lebih memperhatikan jawaban yang dikemukakan temannya ketika presentasi di depan kelas.

Data hasil observasi Siklus II ditunjukkan dalam tabel 2. merujuk pada tabel tersebut, terjadi perubahan aktivitas belajar siswa dibandingkan Siklus I karena perubahan yang terjadi cukup signifikan. Kegiatan menulis dan membaca berkurang menjadi $33 \%$, peningkatan terjadi pada kegiatan mengerjakan LKS $41 \%$, kemudian bertanya pada guru menurun menjadi $5 \%$, dan bertanya pada teman meningkat menjadi $18 \%$. Kegiatan tidak relevan dengan KBM masih muncul dengan proporsi $3 \%$.

Tabel 3. Aktivitas Belajar Siswa Siklus II

\begin{tabular}{|c|l|c|c|}
\hline No & \multicolumn{1}{|c|}{ Aktivitas } & Skor & Proporsi \\
\hline 1 & Menulis dan membaca & 88 & $33 \%$ \\
\hline 2 & Mengerjakan LKS & 111 & $41 \%$ \\
\hline 3 & Bertanya pada guru & 13 & $5 \%$ \\
\hline 4 & Bertanya pada teman & 49 & $18 \%$ \\
\hline 5 & $\begin{array}{l}\text { Yang tidak relevan } \\
\text { dengan KBM }\end{array}$ & 9 & $3 \%$ \\
\hline & JUMLAH & 270 & $100 \%$ \\
\hline
\end{tabular}

Untuk data hasil belajar siswa Siklus II merujuk pada tabel 4 menunjukkan nilai terendah sebesar 60 untuk 7 siswa, tertinggi 100 untuk 15 siswa. Dengan KKM sebesar 70 untuk Pendidikan Kewarganegaraan maka siswa dikatakan tuntas sebanyak 44 siswa dari 51 siswa atau ketuntasan klasikal sebesar 86,2\%. Data hasil belajar Siklus II disajikan dalam tabel 4.

Table 4. Nilai Formatif II

\begin{tabular}{|c|c|c|c|c|}
\hline Nilai & Frekuensi & Tuntas & $\begin{array}{c}\text { Ketuntasan } \\
\text { Kelas }\end{array}$ & $\begin{array}{c}\text { Rata- } \\
\text { rata }\end{array}$ \\
\hline 100 & 15 & 15 & & \\
\cline { 1 - 3 } 80 & 29 & 29 & \multirow{2}{*}{$86,2 \%$} & 83,1 \\
\cline { 1 - 3 } 60 & 7 & - & & \\
\hline Jumlah & 51 & 44 & & \\
\hline
\end{tabular}

Merujuk pada tabel 4 dapat dilihat nilai rata-rata tes siswa sebelum diterapakan model pembelajaran Think Pair Share adalah 19,4 dan setelah diterapkan 
model pembelajaran Think Pair Share meningkat menjadi 70,6 pada Siklus I dan 83,1 pada Siklus II.

Berdasarkan hasil observasi aktivitas, tes hasil belajar siswa terhadap mata pelajaran Pendidikan Kewarganegaraan pada siklus II hasil refleksi dengan penerapan model pembelajaran Think Pair Share (TPS) adalah sebagai berikut:

1. Pembelajaran yang dilakukan sudah sesuai dengan RPP.

2. Pembelajaran sudah mencerminkan model Think Pair Share.

3. Guru telah memotivasi siswa sehingga siswa mulai berani mengeluarkan pendapat.

4. Guru telah memberikan penghargaan bagi kelompok yang mempunyai skor tertinggi.

5. Hasil belajar dan aktivitas belajar siswa mengalami peningkatan dibanding siklus I sehingga memenuhi ketuntasan belajar klasikal.

Dari hasil refleksi tersebut telah menunjukkan ketercapaian indikator keberhasilan, sehingga pelaksanaan tindakan siklus II dikatakan berhasil.

Pembelajaran pertemuan pertama pada Siklus I diawali dengan pengelompokkan siswa menjadi 8 kelompok, masing-masing kelompok berjumlah 6 atau 7 orang siswa. Saat pembelajaran berlangsung masih terlihat siswa belum biasa menangkap alur dan konsep yang diberikan guru saat pembelajaran. Hal ini terlihat dari selama proses pembelajaran sebagian siswa hanya sibuk dengan kegiatan mereka masing-masing meskipun guru sudah menegur mereka. Saat presentasi kelompok, masih banyak siswa yang tidak berani untuk menyampaikan hasil diskusinya dan ada siswa yang tidak mengikuti alur jalannya diskusi sehingga siswa tersebut tidak dapat memahami isi pelajaran yang sedang berlangsung.

Pertemuan kedua pada Siklus I, kegiatan pembelajaran dilaksanakan sama seperti pada pertemuan pertama. Mulai dari pengelompokkan, pemberian nomor pada masingmasing siswa. Pertemuan kedua ini siswa sudah mulai beradaptasi dan aktif saat pembelajaran berlangsung. Guru juga ikut memberikan masukkan dalam kerja kelompok jika terdapat perselisihan atau perbedaan pendapat saat diskusi kelompok berlangsung. Kerja sama antar kelompok sudah mulai terlihat. Presentasi kelompok juga berlangsung dengan baik. Namun demikian perolehan nilai rata-rata kelas 70,6 dengan ketuntasan kelas hanya mencapai 52,9\%. Namun ketuntasan klasikal belum mencapai $85 \%$. Hal ini karena pembelajaran Siklus I masih terkendala pada :

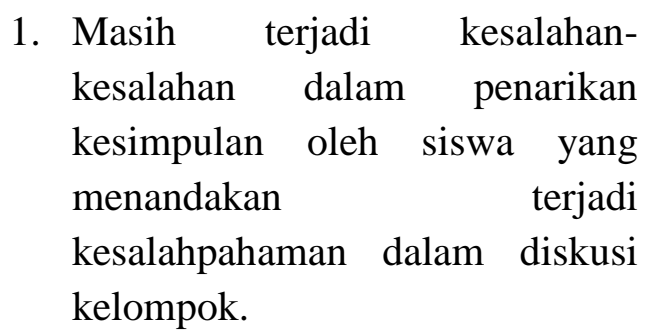


2. Jawaban siswa yang sama dengan jawaban temannya masih banyak hal ini menunjukkan bahwa siswa cenderung untuk menyalin jawaban temannya.

3. Sebagian siswa masih belum terbiasa dengan alur pembelajaran atau masih binggung diperlihatkan dengan besarnya aktivitas menulis dan membaca yang baru dilakukan disekolah (40\%) yang seharusnya sudah dilakukan dirumah.

4. Sebagian siswa belum memiliki rasa tanggung jawab terhadap tugasnya dalam kelompok diperlihatkan dengan aktivitas kerja yang hanya mencapai $32 \%$.

5. Ada siswa yang lebih suka mengerjakan soal sendiri.

6. Pada tahap pengajuan pertanyaan sebagian besar siswa tidak memusatkan perhatian dalam mengerjakan LKS, terbukti masih banyak persentase aktivitas yang tidak relevan dengan KBM yaitu $5 \%$.

7. Pada pertemuan ke II aktivitas siswa sudah mulai meningkat, siswa sudah mulai memperhatikan dan mengerjakan LKS dengan lebih serius.

8. Waktu yang digunakan dalam kegiatan pembelajaran tidak sesuai dengan waktu yang direncanakan sebelumnya.

Sehingga pada penelitian ini masih dilanjutkan pada Siklus II untuk mencapai ketuntasan kelas minimal $85 \%$. Pembelajaran pertemuan pertama pada Siklus II dikondisikan sama seperti pada Siklus I, namun ada beberapa perbaikan pada kelemahan-kelemahan yang terjadi saat pembelajaran pada Siklus I, diantaranya :

1. Penjelasan dan Penekanan kepada siswa tentang pembelajaran Think Pair Share diantaranya kerjasama dalam menyelesaikan tugas, saling membantu dan berdiskusi harus diperhatikan.

2. Guru harus lebih sering mengunjungi kelompok pada tahap berdiskusi bersama berlangsung untuk menghindari siswa ngobrol sendiri di luar materi pelajaran.

3. Guru harus memberikan penghargaan bagi siswa/kelompok yang mendapatkan skor tertinggi dan menyajikan jawaban terbaik.

4. Pengelolaan waktu diharapkan lebih efisien.

5. Guru memberikan informasi kepada siswa bahwa pertanyaanpertanyaan dalam LKS akan ditanyakan kembali pada saat tes agar siswa lebih memperhatikan jawaban yang dikemukakan temannya kepada seluruh kelas.

Hasilnya ada penurunan aktivitas dimana beberapa siswa aktif dalam berdiskusi, bertukar pikiran, bertanya sesama teman (18\%), dan saling memberi masukkan antara kelompok satu dengan kelompok yang lain dengan aktivitas 
mengerjakan $41 \%$. Namun siswa lain masih banyak terlihat menulis-nulis dan membaca buku 33\%. Hal ini membuat manajemen waktu belum terkondisikan dengan baik. Aktivitas tidak relevan masih muncul dengan $3 \%$.

Berdasarkan hasil belajar siswa pada siklus II, perolehan nilai pada Siklus II menunjukkan perolehan nilai rata-rata kelas sebesar 83,1. Ketuntasan kelas pada Siklus II juga meningkat menjadi $86,2 \%$. Terjadi peningkatan baik nilai ratarata maupun ketuntasan klasikal, meski pada Siklus I belum diperoleh hasil yang diharapkan pada Siklus II baru peningkatan sesuai yang diharapkan.

Sehingga terbukti model ini memberikan kesempatan kepada siswa untuk saling membagikan ideide dan mempertimbangkan jawaban yang paling tepat. Selain itu, teknik ini juga mendorong siswa untuk meningkatkan semangat kerja sama mereka. Terbukti dari naiknya aktivitas kerja dan menyusutnya aktivitas individual menulis dan membaca.

Dengan demikian secara keseluruhan dapat dikatakan bahwa proses pembelajaran menggunakan model pembelajaran Think Pair Share (TPS) dapat meningkatkan ketuntasan pembelajaran siswa pada pembelajaran Pendidikan Kewarganegaraan di kelas IV SD Negeri 040460 Berastagi dan berhasil memberi ketuntasan klasikal sampai pada akhir Siklus II. Keadaan tersebut dapat dijadikan sebagai kajian bahwa dengan Siklus yang berulang dan menggunakan model pembelajaran Think Pair Share memungkinkan meningkatkan ketuntasan pembelajaran Pendidikan Kewarganegaraan siswa. Namun demikian penelitian hanya dilaksanakan sampai pada dua Siklus karena keterbatasan dana dan waktu.

\section{SIMPULAN}

Pengambilan data untuk penelitian ini dibagi menjadi dua Siklus, yaitu Siklus I dan Siklus II. Data yang terkumpul antara lain tes hasil belajar kemudian data tersebut dianalisis sehingga dapat disimpulkan antara lain:

1. Aktivitas belajar siswa mengalami peningkatan dari Siklus I ke Siklus II. Data aktivitas siswa menurut pengamatan pengamat pada siklus I antara lain menulis/membaca (40\%), bekerja (32\%), bertanya sesama teman (5\%), bertanya kepada guru (18\%), dan yang tidak relevan dengan KBM (5\%). Data aktivitas siswa menurut pengamatan pada Siklus II antara lain menulis/membaca (33\%), bekerja (41\%), bertanya sesama teman (18\%), bertanya kepada guru (5\%), dan yang tidak relevan dengan KBM (3\%). Ini berarti siswa semakin aktif dalam belajar dengan menerapkan model pembelajaran Think Pair Share. 
2. Hasil belajar siswa pada mata pelajaran PKn dengan menerapkan model pembelajaran Think Pair Share pada siklus I mencapai ratarata 70,6 dengan tuntas secara kelas dan siklus II mencapai 83,1 dengan tuntas secara kelas. Dengan demikian terjadi peningkatan hasil belajar siswa di kelas IV SD Negeri 040460 Berastagi.

\section{DAFTAR RUJUKAN}

Aqib, Zainal, (2006), Penelitian Tindakan Kelas. Yrama Widya, Bandung.

Majid, Abdul, (2009), Perencanaan Pembelajaran

Mengembangkan Standar Kompetensi Guru, Penerbit PT. Remaja Rosdakarya Offset, Bandung.

Mulyasa. (2006). Kurikulum Tingkat Satuan Pendidikan. Penerbit PT Remaja Resdakarya. Bandung.

Sukmadinata, (2006), Metode Penelitian Pendidikan, Rosdakarya, Bandung.

Tarigan, Rosmawati, (2015), Penerapan Model Pembelajaran Think Pair Share (Tps) Dalam Meningkatkan Hasil Belajar Siswa Pada Mata Pelajaran Pkn Di Kelas Iv Sd Negeri
040460 Berastagi Semester Ganjil T.P. 2015/2016. UD Toma, Medan.

Widarti, Atik, (2007), Efektifitas Penggunaan Model Pembelajaran Kooperatif Tipe Think Pair Share terhadap Hasil Belajar Siswa Pokok Bahasan Segia Empat Pada Siswa Kelas IV Semester 2. (Online), Tersedia: http://gigilib.unnes.ac.id/gsdl/ cgi-bin/library. 